\title{
The Effect of Food Safety Education on Handwashing Practices in School Canteens' Food Handlers
}

(Kesan daripada Aktiviti Pendidikan Keselamatan Makanan ke atas Amalan Membasuh Tangan oleh Pengendali Makanan Kantin Sekolah)

\author{
NiK RosmaWATI NH*, Wan MANAN WM, NOOR IZANi NJ, NIK NURAIN NH \& RAZLINA AR
}

\begin{abstract}
This study aims to assess the effectiveness of a newly developed food safety education to improve the handwashing practices offood handlers in school canteens. A community-based intervention study was carried out over a 2-year period. Sixteen out of 98 primary schools were randomly selected and assigned into intervention and control groups using a simple random sampling method. The study population included food handlers who worked in the canteens of the school selected. The Food Safety Education Programme (FSEP) for the intervention group was developed based on the theory of planned behaviour. The main outcome measures used were handwashing practices from the observations carried out at baseline, 6-weeks (Post1) and 12-weeks (Post2) after the intervention. Out of 79 food handlers who participated in this study, 33 (41.8\%) were in the intervention group and 46 (58.2\%) were in the control group. Prior to FSEP, handwashing was not commonly practiced following critical events and the majority did not perform correctly. The time-effect of the mixed design analysis of variance showed a significant increase $(\mathrm{p}=0.004)$ in the mean percentage of the total observed handwashing practices from $29 \%$ at the baseline to $50.8 \%$ at Post $1(\mathrm{p}=0.004)$. However, the intervention-effect of mixed design ANOVA did not show any significant difference in the handwashing practices $(\mathrm{p}=0.210)$. The FSEP was effective in improving the handwashing practices of the food handlers in the selected primary school canteens.
\end{abstract}

Keywords: Food safety; handwashing; intervention; school canteen; theory of planned behavior

ABSTRAK

Kajian ini bertujuan untuk menilai keberkesanan pendidikan keselamatan makanan yang baru dibangunkan untuk meningkatkan amalan membasuh tangan oleh pengendali makanan di kantin sekolah. Kajian intervensi berasaskan komuniti ini telah dijalankan dalam tempoh 2 tahun. Enam belas daripada 98 sekolah dipilih secara rawak dan diperuntukkan kepada campur tangan dan kawalan kumpulan yang menggunakan kaedah persampelan rawak mudah. Populasi kajian termasuk pengendali makanan yang bekerja di kantin sekolah yang dipilih. Program Pendidikan Keselamatan Makanan (FSEP) bagi kumpulan intervensi telah dibangunkan berdasarkan teori tingkah laku terancang. Langkah hasil utama yang digunakan adalah amalan basuh tangan daripada pemerhatian yang dijalankan secara dasar, 6-minggu (Post1) dan 12 minggu (Post2) selepas campur tangan. Daripada 79 pengendali makanan yang mengambil bahagian dalam kajian ini, 33 (41.8\%) berada dalam kumpulan intervensi dan 46 (58.2\%) adalah dalam kumpulan kawalan. Sebelum FSEP, membasuh tangan bukanlah amalan biasa dan kebanyakannya tidak dilakukan dengan betul. Masa-kesan analisis varians reka bentuk campuran menunjukkan peningkatan ketara $(\mathrm{p}=0.004)$ pada min peratusan daripada jumlah keseluruhan amalan basuh tangan yang diperhatikan daripada $29 \%$ pada asas kepada $50.8 \%$ pada Post1 (p=0.004). Walau bagaimanapun, campur tangan-kesan reka bentuk campuran ANOVA tidak menunjukkan sebarang perbezaan yang signifikan dalam amalan membasuh tangan $(\mathrm{p}=0.210)$. FSEP ini adalah berkesan dalam meningkatkan amalan membasuh tangan pengendali makanan di kantin sekolah rendah terpilih.

Kata kunci: Campur tangan; kantin sekolah; keselamatan makanan; membasuh tangan; teori tingkah laku terancang

\section{INTRODUCTION}

For decades, food handlers in various settings have been responsible for foodborne disease outbreaks through various means (Chapman et al. 2010; Sharif et al. 2013). The health violations committed by food handlers have been observed during food preparation, processing, or storage (Sani et al. 2014). Current study on hygiene and sanitation practices of school canteen in Philippine found poor practices among their food handlers (Pascual 2016).
In some cases, food handlers had been reported as to be the carriers of pathogenic microorganism (Chapman et al. 2011; Simonne et al. 2010) such as Hepatitis A, Salmonella spp. and E. coli O157:H7. Thus, they can be the vectors in spreading foodborne diseases through crosscontaminations (Bas et al. 2006). In view of that, Simonne et al. (2010) pointed out the major route of infection when the hygiene status is ignored or violated would be the faecal-oral transmissions. 
Based on the verified outbreaks in Europe which involved a large number of human cases, it has been proven that school canteens were the second most common settings reported following the outbreaks in restaurants (EFSA 2010). A substantial number of foodborne outbreaks were reported in Japan (Somura et al. 2017) and Sweden (Hergens et al. 2017) involving school children. Similarly, the school age group was more affected than the general population in Malaysia (Meftahuddin 2002). Half of the foodborne diseases reported in Malaysia from the early 1990 s until today were associated with the outbreaks in academic institutions and schools, with $62 \%$ of the episodes in schools, followed by academic institutions (17\%), while community gatherings accounted for $8 \%$ (Soon et al. 2011) of the occurrences. The presence of microbial contaminations in food prepared in school canteens largely owed to the cross-contaminations caused by food handlers (Ryu et al. 2011).

A good personal hygiene should include appropriate handwashing practices by all food handlers. An observational study conducted to determine the handwashing practices amongst food handlers in a primary school canteen in Kuala Langat, Malaysia reported that all $100 \%$ of them did not wash their hands using the proper techniques (Tan et al. 2013). An earlier study assessed food safety and associated food handling in the street food vending found the self-reported handwashing among food handler prior to food handling and preparation, was less than 5\% (Lues et al. 2006). Therefore, to reduce the risk of foodborne disease in school, serious attention should be given along the process of food preparation especially to ensure proper handwashing practices is a standard practice amongst food handlers.

The risk of foodborne diseases could be reduced significantly by just practicing a simple step of effective handwashing technique and by undergoing effective food safety training (Abdullah Sani \& Siow 2014; Lee \& Greig 2010). However, Pragle et al. (2007) claimed there were a few barriers that hinder food handlers from practicing good hand hygiene, and they proposed some recommendations for the future educational and training programmes to improve the handwashing practice. An effective training programme should include a hands-on training programme in order to orient the correct handwashing practice. This is particularly crucial to new employees and the involvement of both the managers and co-workers in such training are also imperative. Finally, to ensure that the knowledge about correct handwashing practices can be implemented effectively, the food establishments themselves should be equipped with the necessary supplies.

Though all food handlers are legally required to attend the current food handlers' training programmes, it was observed that their hygienic practices are still inadequate. At the same time, foodborne diseases are showing alarming increasing trends especially in schools. Thus, one could question the effectiveness of the existing training programmes and whether their efficacy is regularly evaluated, as argued by Chapman et al. (2010).
The purpose of this study was to determine the effect of food safety education, using the theory of planned behaviour (TPB) framework, on the handwashing practices among food handlers in primary-school canteens. We hypothesised that following the intervention; food handlers will show significant improvements in the handwashing practices.

\section{MATERIALS AND METHODS}

\section{RESEARCH POPULATION AND DATA COLLECTION}

A community-based intervention study was conducted from January 1,2013, until November 31,2014 at primary school canteens in Kota Bharu, Kelantan, Malaysia. Sixteen schools were selected out of 98 listed standard primary schools by using a simple random sampling. These selected schools were then randomly assigned to the intervention and control groups, resulting in eight schools as being categorized in the intervention group and another eight as the control group. All the food handlers from each selected school canteen who fulfilled the inclusion and exclusion criteria and signed the consent forms were recruited as respondents. Those aged between 18 and 55, had attended Food Handlers' Training Programme certified by the Ministry of Health Malaysia and involved in food handling and preparation were involved. Whereas, illiterate food handlers, those with the intention to change work within a year and had a history of mental illness were excluded. The process for the selection of the unit samples and respondents is summarised in the flow chart presented in Figure 1.

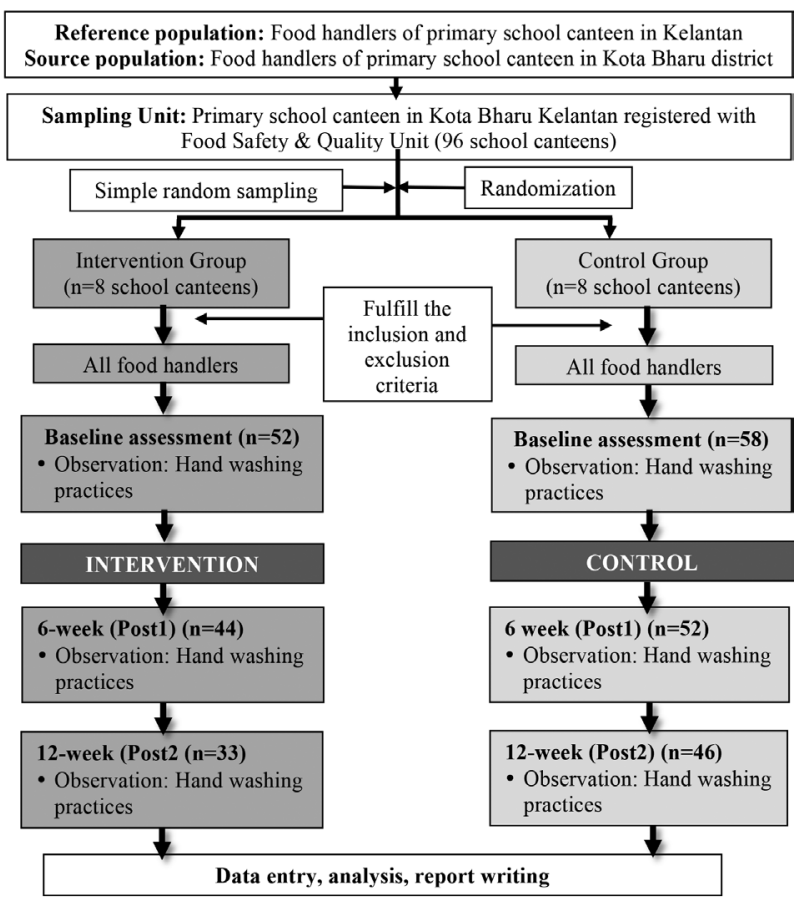

FIGURE 1. Study flow chart 
The sample size was determined using the power and sample size calculation software version 3.0.43 for comparison of two means. Taking a standard deviation of the mean practice score in the control group of 12.11 (Zain 2001), an estimated mean difference of food safety practice among food handlers in intervention and control groups of 8 that was based on the total mean score of the food safety practice in the population of 48.4 in a previous study (Bas et al. 2006), the power of 0.8 , the Type 1 error of 0.05 and the ratio between the intervention and the control group of 1 , thus, the minimum required sample size was 42 per group. After anticipating a $20 \%$ drop out in the 3 -months follow-up, the required sample size was 50 per group.

\section{INTERVENTION PLAN AND MATERIALS}

The information from the pilot study, a review of the literature (Park et al. 2010), the American College of Occupational and Environmental Medicine Guidelines (Simonne et al. 2010), the Catering Industry Guide to Good Hygiene (Seaman \& Eves 2006), the Food Act (1983) and the Food Regulations (2009) were used for the content development of the Food Safety Education Programme (FSEP). This study targeted three enabling factors for behavioural change: the behavioural attitude, normative beliefs and perceived behavioural control as elaborated in the ТРВ (Ajzen 1991; Rennie 1995). То evaluate the appropriateness and operational feasibility of the training module, ten experts in the field, including two food handlers and two food managers reviewed the FSEP and discussed it in detail during a workshop to gain the final consensus and improvements were also made.

The FSEP targeted behavioural attitudes by providing information on the hazards or risks likely to be present if they do or do not follow the food safety guidelines. Food handlers received training regarding the good and bad practices, common pitfalls in food safety practices, the risk of cross-contamination, the common aetiologies of foodborne diseases, the health and economic effects associated with foodborne disease outbreaks, the people at risk, and related laws and regulations. To improve the normative beliefs, the wishes of the important people pertaining to these issues were shared with food handlers and managers. The key message included the need to comply with relevant acts and regulations, the responsibilities of food managers and the skills of handwashing. In targeting the perceived behavioural control, the FSEP focused on reducing the barriers, improving beliefs and improving the participants' self-capability to perform the intended behaviours. The training included simple steps to prevent food contamination and the steps in the $25 \mathrm{~s}$ handwashing procedure. There were health talks, $25 \mathrm{~s}$ handwashing demonstrations and self-practice and posters, wiping cloths and a tissue-paper roll with its holder were provided.

The FSEP was implemented in the intervention group in two sessions with an interval of one week between the sessions. The first session covered the role of food handlers and food managers in preventing the occurrence of food poisoning (60 min). Following a $20 \mathrm{~min}$ rest, a second session covered simple measures to prevent foodborne diseases (50 min). A week after that, FSEP focused on the $25 \mathrm{~s}$ procedure of properly washing the hands ( $85 \mathrm{~min}$ ). The education programme was implemented on weekends for the purpose of ensuring full attendance of the participants, since the canteens did not operate on weekends. Finally, researchers conducted site visits to each of these school canteens in the intervention group three weeks after the completion of the education programme. The foremost purpose of the site visits was to constantly motivate the participants to execute handwashing practices, to strengthen the given knowledge and skills, and to help solve any barriers or difficulties, if present.

\section{DATA COLLECTION}

This study assessed handwashing practices of food handlers through a direct observation. Site visits for each school canteen were carried out one month prior to the education programme to collect baseline data. Data were also collected at 6-week (Post1) and at 12-week (Post2), after the participants completed the FSEP. Handwashing practices were observed based on a checklist. The checklist constituted seven observed events that participants needed to do in order to ensure that their hands were washed properly as follows: Wash hands prior to food preparation; wash hands after handling raw meat; wash hands after eating or drinking; wash hands after coughing or sneezing; wash hands after handling dirty equipment; wash hand after touching my own body parts; and wash hands after using toilet. There were three columns provided for each stated event that the researcher needed to observe: the number of handwashing practice that they were supposed to perform, the actual number of handwashing practices they performed and the method of handwashing that they practiced.

Two researchers evaluated the handwashing behavior of the food handlers. Each researcher observed a maximum of two food handlers simultaneously for an hour. For every event listed in the checklist, the researchers had to monitor the handwashing practices, performed at appropriate times and with proper technique. For example, after handling raw food, food handlers were supposed to wash their hands, thus, noted as one occasion or event in the first column (supposed to wash hands). If they wash their hands, then, it was regarded as one occasion in the second column (actual number of handwashing following the event supposed to wash hands). If they washed their hands following the proper steps, then the respective food handler was noted as performing the correct handwashing practice in the last column. If the researchers observed a respondent washing his or her hands prior to food handling on four occasions and observed the respondent not doing so on three other occasions, the total number of observations would be seven, making the percentage of handwashing practice $57.1 \%$. If the researchers found 12 respondents performed the correct method of handwashing technique 
out of 20 respondents who performed the handwashing following the specific event, the percentage for the correct method of performing handwashing behaviours was $60 \%$. Throughout the observation, the food handlers were unaware of which behaviours they were being monitored. Later, the proportions of handwashing practices of these seven observed events were combined into a total observed handwashing practice for further analysis.

Data gathered were entered into and analysed using IBM SPSS Statistics version 22.0. The Pearson Chi-square and Independent $t$ test analyses were used to compare the differences of categorical variables and numerical variable in the sociodemographic characteristics of participants respectively. The mixed design ANOVA was applied to compare the mean percentage of food safety practices between trained food handlers and non-trained food handlers at the baseline, 6-week (post1) and 12-week (post2) after FSEP. A p-value of less than 0.05 was taken as significant. Model assumptions like the normality of residuals, homogeneity of variance and compound symmetry were verified.

\section{RESULTS}

Of 16 primary school canteens, the majority were from the National Primary School with only one $(6.25 \%)$ was the Chinese National type Schools. Baseline data successfully recruited 110 food handlers consisted of 52 food handlers $(47.3 \%)$ in the intervention group and another 58 food handlers $(52.7 \%)$ in the control group. Post 1 data collection revealed $12.7 \%$ of them dropped out which amounted to 8 respondents in the intervention group and the remaining 6 respondents from the control group. Post 2 data collection found another $15.5 \%$ drop out which amounts to 11 respondents from the intervention group and 6 respondents from the control group.

Table 1 shows the sociodemographic characteristics of food handlers in 16 primary schools in Kota Bharu Kelantan. Out of 79 food handlers who participated in this study up to post 2 of the data collection, $33(41.8 \%)$ in the intervention group and $46(58.2 \%)$ in the control group. The majority of them are female, Malay, with middle level education and in the middle age group. The overall family income (the managers and employees) is RM1403.80 and RM1228.48 in the intervention and control group, respectively. Further analysis of the monthly family income amongst the employees found the mean family income is RM805.79 (minimum RM400, maximum RM1700) and RM987.20 (minimum RM320, maximum RM2400) in the intervention and control group, respectively. Both groups are homogenous since no significant differences in terms of the sociodemographic, working experience, working duration, latest attended a food safety course between intervention and control groups.

\section{OBSERVED HANDWASHING PRACTICES}

The mean percentage and standard deviation of the observed handwashing practices and the percentage of performing the correct method of handwashing for each event are presented in Table 2. The table also illustrates the number of food handlers and the percentages of the correct method in performing handwashing. It is derived

TABLE 1. Sociodemographic characteristics of food handlers in the intervention $(n=33)$ and control $(n=46)$ groups

\begin{tabular}{|c|c|c|c|c|}
\hline \multirow[t]{2}{*}{ Characteristics } & Intervention group & Control group & \multirow{2}{*}{$\begin{array}{l}\text { Test statistics } \\
\text { (df) }\end{array}$} & \multirow[t]{2}{*}{$P$ value } \\
\hline & Freq $(\%)$ & Freq $(\%)$ & & \\
\hline \multicolumn{5}{|l|}{ Gender } \\
\hline Male & $2(2.5)$ & $6(7.6)$ & & $0.267^{\mathrm{b}}$ \\
\hline Female & $31(39.2)$ & $40(50.6)$ & & \\
\hline \multicolumn{5}{|l|}{ Race } \\
\hline Malay & $31(39.2)$ & $46(58.2)$ & & $0.171^{\mathrm{b}}$ \\
\hline Non-Malay & $2(2.5)$ & $0(0)$ & & \\
\hline \multicolumn{5}{|l|}{ Education level $^{\mathrm{d}}$} \\
\hline Low & $4(5.1)$ & $5(6.3)$ & $0.851(2)$ & $0.654^{\mathrm{a}}$ \\
\hline Middle & $27(34.2)$ & $40(50.6)$ & & \\
\hline High & $2(2.5)$ & $1(1.3)$ & & \\
\hline Age (year) & $42.73(10.68)$ & $44.96(11.14)$ & $0.892(77)$ & $0.375^{\mathrm{c}}$ \\
\hline Working experience as food handlers (month) & $44.97(47.05)$ & $90.37(158.00)$ & $1.598(77)$ & $0.114^{\mathrm{c}}$ \\
\hline Working duration at current food establishment (month) & $29.58(28.01)$ & $45.52(66.31)$ & $1.299(77)$ & $0.198^{\mathrm{c}}$ \\
\hline Last attended food safety course (year) & $2.64(3.02)$ & $2.89(2.11)$ & $0.442(77)$ & $0.660^{\mathrm{c}}$ \\
\hline Family income (RM) & $1403.80(2050.51)$ & $1228.48(1742.37)$ & $-0.410(77)$ & $0.683^{\mathrm{c}}$ \\
\hline
\end{tabular}

${ }^{a}$ Chi-square test

'Fisher's Exact test

'Independent $\mathrm{t}$ test

${ }^{\mathrm{d}}$ Education level;

Low $=$ up to primary school

Middle $=$ up to secondary school

High $=$ diploma $/$ degree 
TABLE 2. Handwashing practices and the correct method of handwashing among food handlers at baseline assessment $(n=79)$

\begin{tabular}{|c|c|c|}
\hline Observed practice & $\begin{array}{c}\text { \%andwashing } \\
\text { practices }^{\mathrm{a}} \\
\text { Mean }^{\mathrm{b}}(\mathrm{sd})\end{array}$ & $\begin{array}{c}\text { Correct method } \\
\text { handwashing } \\
\mathrm{n}(\%)^{\mathrm{c}}\end{array}$ \\
\hline Wash hands prior to food preparation & $3.09(36.35)$ & 0 \\
\hline Wash hands after handling raw meat & $67.00(44.73)$ & 0 \\
\hline Wash hands after eating or drinking & $11.90(27.46)$ & 0 \\
\hline Wash hands after coughing or sneezing & $5.56(16.67)$ & 0 \\
\hline Wash hands after handling dirty equipment & $39.72(32.91)$ & $4(5.6)$ \\
\hline Wash hands after touching my own body parts & $5.00(19.66)$ & $2(4.3)$ \\
\hline Wash hands after using toilet & $25.00(42.49)$ & 0 \\
\hline Total observed handwashing practices & $32.53(27.23)$ & $6(2.5)$ \\
\hline
\end{tabular}

a\% Handwashing practices $=$ number of performing hands washing/number of handwashing behaviour supposed they perform $\times 100$ ${ }^{b}$ Mean percentage

${ }^{c}$ Percentage of perform correct method handwashing = number of food handlers perform correct method handwashing/number of food handlers perform handwashing $\times 100$

by dividing the number of food handlers who perform correct handwashing practice with the total number of food handlers who perform the hands washing times 100 for each observed event. At the baseline, handwashing following critical events were not commonly practiced by food handlers. The poorest handwashing practice was following 'after touching my own body parts'. Furthermore, out of those who performed handwashing, none of them performed the correct method unless, following 'after handling dirty equipment' and 'after touching my own body parts' which are only $5.6 \%$ and $4.3 \%$, respectively.

Table 3 shows the descriptive results of the observed handwashing practices based on the respective groups for each time of measurement. At the baseline, the control group shows higher percentage of food handlers practicing handwashing after using the toilet compared to the intervention group. However, following the intervention, trained food handlers demonstrate the higher percentage. The control group is found to be zero in handwashing practices after coughing or sneezing throughout the three measurements. Table 3 also illustrates a high proportion of the trained food handlers who perform the correct method of handwashing at both Post 1 and Post 2 in each of the element assessed compared to the control group.

\section{CHANGES OF OBSERVED HANDWASHING PRACTICES} WITHIN GROUP BASED ON TIME (TIME-EFFECT)

The time-effect mixed design ANOVA analysis (Table 4) shows that there are significant differences of mean percent of total observed handwashing practices based on time $(\mathrm{F}(2,156) 3.264, p=0.041)$. Pairwise comparison with confidence interval adjustment (Bonferroni) indicates that, from within group analysis of the intervention group, there are significant differences of mean percentage of total observed in the handwashing practices between baseline and Post1 $(p=0.004)$. The trained food handlers significantly practiced better handwashing 4-weeks after the FSEP compared to the baseline (mean differences $=-21.84$,
$95 \% \mathrm{CI}=-37.37,-6.30)$. There is also $15.5 \%$ increment in the number of handwashing practices following 3-months FSEP in the intervention group compared to the baseline. However, the difference is not significant $(p=0.066)$. For the control group, there is no significant difference in the handwashing practices in all the comparisons.

COMPARISON OF THE OBSERVED HANDWASHING PRACTICES BETWEEN GROUPS, REGARDLESS OF TIME

Table 5 shows the intervention-effect from mixed design ANOVA based on the Tests of Between-Subjects Effects. Overall, regardless of time the trained group demonstrates $5.68 \%$ higher mean proportion in handwashing practices compared to the control group. However, the difference is not significant $(p=0.210)$.

\section{COMPARISON OF THE OBSERVED HANDWASHING PRACTICES BETWEEN GROUPS BASED ON TIME}

The F-statistics from within-between group comparison of the total observed handwashing practices show no significant time-intervention interaction as the p-value is larger than the 0.05 (Wilks' Lambda $\mathrm{F}(2,75)=2.894$, $p=0.062$ ). The Partial $E t a^{2}$ value for this interaction was 0.18 suggesting small effect size (Lakens 2013). Figure 2 shows the profile plot of the estimated marginal mean of the total observed handwashing practices in both groups. At the baseline, control group demonstrated better handwashing practices compared to intervention group. Following the intervention, the trained group demonstrates a marked improvement at Post 1 and Post 2 when compared to a little improvement in the control group. However, these timeeffect increments are not statistically significant.

\section{DISCUSSION}

Poor hand hygiene practices among food handlers who work in school canteens can contribute to crosscontamination, which pose the risks of foodborne disease 
TABLE 3. Descriptive statistics of observed handwashing practices based on groups and times

\begin{tabular}{|c|c|c|c|c|}
\hline \multirow{2}{*}{$\begin{array}{l}\text { Observed } \\
\text { practice }\end{array}$} & \multicolumn{2}{|c|}{$\%$ Handwashing practices ${ }^{\mathrm{a}}$} & \multicolumn{2}{|c|}{ Correct method handwashing } \\
\hline & $\begin{array}{c}\text { Intervention }(n=33) \\
\operatorname{Mean}^{\mathrm{b}}(\mathrm{sd})\end{array}$ & $\begin{array}{l}\text { Control }(n=46) \\
\operatorname{Mean}^{\mathrm{b}}(\mathrm{sd})\end{array}$ & $\begin{array}{c}\text { Intervention }(n=33) \\
n(\%)^{\mathrm{c}}\end{array}$ & $\begin{array}{c}\text { Control }(n=46) \\
n(\%)^{\mathrm{c}}\end{array}$ \\
\hline \multicolumn{5}{|c|}{ Wash hands prior to food preparation } \\
\hline Baseline & $35.84(36.83)$ & $29.23(36.17)$ & 0 & 0 \\
\hline Post1 & $32.33(38.60)$ & $23.65(36.03)$ & 0 & $1(2.70)$ \\
\hline Post2 & $43.44(38.72)$ & $36.99(37.41)$ & $9(90.0)$ & $3(10.42)$ \\
\hline \multicolumn{5}{|c|}{ Wash hands after handling raw meat } \\
\hline Baseline & $42.50(43.49)$ & $83.33(40.82)$ & 0 & 0 \\
\hline Post1 & 77.78 (44.10) & $75.00(45.23)$ & $2(20.0)$ & 0 \\
\hline Post2 & $47.73(46.71)$ & $23.33(41.72)$ & $9(81.8)$ & 0 \\
\hline \multicolumn{5}{|c|}{ Wash hands after eating or drinking } \\
\hline Baseline & $10.42(19.80)$ & $12.82(32.03)$ & 0 & 0 \\
\hline Post1 & $33.33(50.00)$ & $27.27(46.71)$ & $6(66.7)$ & 0 \\
\hline Post2 & $45.00(55.03)$ & $13.89(33.46)$ & $7(70.0)$ & 0 \\
\hline \multicolumn{5}{|c|}{ Wash hands after coughing or sneezing } \\
\hline Baseline & $8.33(20.41)$ & 0 & 0 & 0 \\
\hline Post1 & $100(100.0)$ & 0 & $4(100.0)$ & 0 \\
\hline Post 2 & $57.14(53.45)$ & 0 & $4(100.0)$ & 0 \\
\hline \multicolumn{5}{|c|}{ Wash hands after handling dirty equipment } \\
\hline Baseline & $39.76(32.37)$ & $40.59(33.44)$ & $4(14.3)$ & 0 \\
\hline Post1 & $61.74(35.57)$ & $45.42(40.94)$ & $8(25.8)$ & $3(6.7)$ \\
\hline Post2 & $52.04(34.03)$ & $44.88(36.79)$ & $15(50.0)$ & $14(20.59)$ \\
\hline \multicolumn{5}{|c|}{ Wash hands after touching my own body parts } \\
\hline Baseline & $3.95(17.21)$ & $5.77(21.57)$ & $2(10.0)$ & 0 \\
\hline Post1 & $27.38(41.01)$ & $17.67(39.30)$ & $5(35.7)$ & 0 \\
\hline Post2 & $31.25(47.87)$ & $14.67(25.05)$ & $9(56.3)$ & $2(6.7)$ \\
\hline \multicolumn{5}{|c|}{ Wash hands after using toilet } \\
\hline Baseline & $10.00(22.36)$ & $40.00(54.77)$ & 0 & 0 \\
\hline Post1 & $75.00(50.00)$ & 0 & $3(100.0)$ & 0 \\
\hline Post2 & $100(100.0)$ & $25.00(46.29)$ & $4(100.0)$ & 0 \\
\hline \multicolumn{5}{|c|}{ Total observed handwashing practices } \\
\hline Baseline & $29.00(24.17)$ & $35.06(29.23)$ & $6(5.8)$ & 0 \\
\hline Post1 & $50.83(30.58)$ & 36.53 (33.99) & $28(27.7)$ & $4(3.2)$ \\
\hline Post2 & $44.52(31.97)$ & $37.59(29.84)$ & $57(67.1)$ & $19(15.0) 127$ \\
\hline
\end{tabular}

a\% Handwashing practices $=$ number of performing hands washing/number of handwashing behaviour supposed they perform $\times 100$

${ }^{b}$ Mean percentage

'Percentage of perform correct method handwashing $=$ number of food handlers perform correct method handwashing / number of food handlers perform handwashing $\times 100$

TABLE 4. Comparison of mean percentage for observed handwashing practices within each group based on time $(n=79)$

\begin{tabular}{lcccc}
\hline & \multicolumn{2}{c}{ Intervention group $(n=33)$} & \multicolumn{2}{c}{ Control group $(n=46)$} \\
\cline { 2 - 5 } Comparison & $\begin{array}{c}\text { MD }^{\mathrm{b}} \\
(95 \% \mathrm{CI})\end{array}$ & $p$-value & $\begin{array}{c}\text { MD }^{\mathrm{a}} \\
(95 \% \mathrm{CI})\end{array}$ & $p$-value $^{\mathrm{a}}$ \\
\hline Baseline - Post1 & $-21.84(-37.37,-6.30)$ & 0.004 & $-2.91(-16.70,10.88)$ & $>0.05$ \\
Baseline - Post2 & $-15.52(-31.82,0.78)$ & 0.066 & $-3.53(-17.20,10.13)$ & $>0.05$ \\
Post1 - Post2 & $6.32(-10.60,23.24)$ & $>0.05$ & $-0.62(-18.59,17.35)$ & $>0.05$ \\
\hline
\end{tabular}

aThe mixed design ANOVA within group analysis was applied

${ }^{\mathrm{b}} \mathrm{MD}=$ mean percentage difference 
TABLE 5. Mean percentage difference of observed handwashing practices between intervention and control groups, regardless of time $(n=79)$

\begin{tabular}{cccc}
\hline \multirow{2}{*}{ Variable } & $\begin{array}{c}\text { Mean difference } \\
(95 \% \mathrm{CI})\end{array}$ & \multicolumn{2}{c}{ Repeated measure ANOVA $^{\mathrm{b}}$} \\
\cline { 3 - 4 } Observed handwashing practices & $5.68(-3.27,14.63)$ & $1.597(1,76)$ & 0.210 \\
\hline
\end{tabular}

${ }^{a}$ Repeated measure of ANOVA between group analysis was applied ${ }^{b}$ mean percentage difference

Level of significance was set at 0.05 (two-tailed)

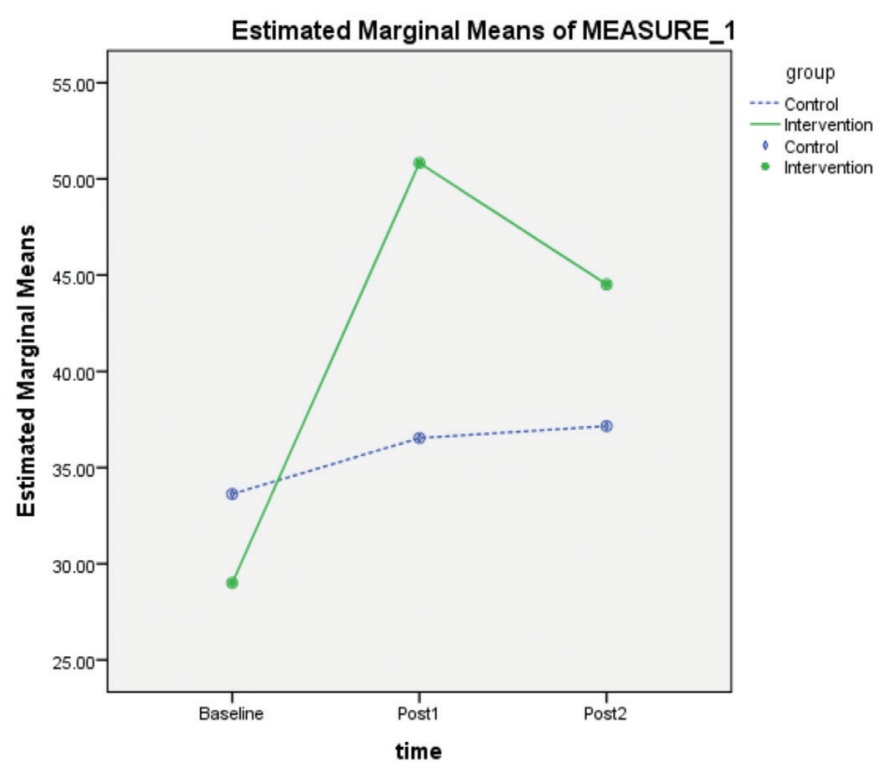

FIGURE 2. Profile plot shows the estimated marginal mean of the total observed handwashing practices for intervention and control group

outbreaks among school children. The necessity of handwashing has been clearly stipulated in some local legislation. Furthermore, it has been stated that no person will be allowed to handle food intended for consumption if their hands are not washed with soap and water, as well as the need to provide soap and disposable paper towels (Lues et al. 2006).

The results from this study have shown that prior to the FSEP, food handlers in school canteens had poor level of practiced handwashing. Overall, less than $30 \%$ of the food handlers in both groups performed handwashing practices following critical events. In terms of the correct method of handwashing practices, the overall results indicated that less than $6 \%$ performed it correctly. In contrast, based on findings by Tan et al. (2013) regarding self-reported handwashing practices, more than $95 \%$ of the food handlers in the school canteens washed their hands as indicated except after drinking and eating (36\%), and $12 \%$ were able to describe a reasonable procedure for handwashing. The current study conducted on-site observation to determine the handwashing practices thus, it showed more precise hand hygiene practices among food handlers in school canteens, indicating the need for an immediate effective education or training be given to them.
Further findings have found that participants of the FSEP had significantly improved their handwashing frequency up to 6 weeks after the intervention. The percentage of handwashing practices in the intervention group had increased from $29 \%$ at the baseline to $50.8 \%$ 6 weeks after the intervention. These findings also show $15.5 \%$ increment of the handwashing practices by the trained food handlers in Post 2 compared to the baseline. However, this increment was not statistically significant. Moreover, the impact of the intervention was documented based on the increment in the proportion of correct handwashing in all the observed conditions in the intervention group compared to the control.

This study has proven the positive impacts of the FSEP based on the TPB framework of handwashing practices. These results were in line with a past study that evaluated the food safety training for food handlers in restaurants (Park et al. 2010). That study concluded that hands-on training is needed to ensure a positive training outcome. A study conducted by York et al. (2009) reported similar positive impacts of ТРВ-based intervention targeting proper handwashing among food handlers. The significant impact of the current FSEP was most likely due to targeting of multiple behaviours. This education programme has 
employed the persuasion and motivation techniques in order to influence the intention to wash hands in the correct manner. These messages were delivered through interactive presentations, demonstration, self-practice, posters and provision of wiping cloth and tissue papers.

Moreover, the education programme did take into consideration time-constraint barriers to perform handwashing, as stated by previous researchers (Boyce \& Pittet 2002; Webb \& Morancie 2015). The current handwashing technique would only require a shorter $25 \mathrm{~s}$ to accomplish compared to the routine practice (almost $60 \mathrm{~s}$ ). Researchers believe that the shorter timerequirement would increase their control over the barrier, thus, improving the behaviour or the intention to change the behaviour. This handwashing time frame is in line with what was discussed with Brannon et al. (2009). They defined proper handwashing as washing hands with soap and hot water for 20-30 s and drying (with an air dryer or single-use paper towels). Chapman et al. (2010) also have concluded that the handwashing duration was not considered as a factor for correctness, as it had not been demonstrated as a critical pathogen reduction factor. According to Boyce and Pittet (2002), washing hands with plain soap and water for $15 \mathrm{~s}$ would successfully reduce bacterial counts on the skin by $0.6-1.1 \log 10$.

A recommendation was made for innovations in food service operational behaviours such as the addition of quick-use, alcohol-based hand sanitisers at workstations, as used in the health care settings (Chapman et al. 2010). However, U.S. Food and Drug Administration (FDA 2003) did not recommend such uses in food establishments due to the differences in controlling common nosocomial pathogens in healthcare settings and common foodborne pathogens in retail and food service settings.

The provisions of wiping cloth and tissue papers were thought to reduce the barrier to perform the correct handwashing technique. Previous studies had pointed out that the most common factor leading to incorrect handwashing behaviours among food handlers (93\%) was the lack of proper hand drying and paper towel (Chapman et al. 2010; Sharma et al. 2016). Meanwhile, the use of posters alone as an education tool (Anderson et al. 2014) or education without hands-on training (Park et al. 2010) has failed to improve handwashing practices. Past researchers have suggested that providing active training sessions such as demonstrations of behaviours and having hands-on practice, either in class or at the job site, in order to improve the standards handwashing training, which is often provided in a passive lecture and video presentation, would end up with lack of impact (Lillquist et al. 2005).

This current study has assessed handwashing practices through on-site observations. This is considered as the strength of this study because it is a more accurate representation of the actual hand hygiene behaviours compared to self-reports, even though it did require extra costs and time to be conducted. O'Boyle et al. (2001) supported the argument of observed handwashing being better than self-reports. They reported the correlation between observed and self-reported handwashing to be 0.22 , indicating the inadequacy of the self-report approach.

This study shows a significant number of dropouts and considered that as the study's limitation. The overall dropout rate was $28.2 \%$, representing 14 and 17 food handlers during Post 1 and Post2, respectively. This value outnumbered the $20 \%$ anticipated dropout rate during the sample size calculation. Reasons for dropping out included switching to jobs with better salaries, the delivery of new babies for female food handlers and the employers were not satisfied with the work performance of their employees. The dropouts were already anticipated prior to the commencement of data collection. This study only enrolled food handlers with the intention to work at the same school canteens within a one-year period. Moreover, the anticipated $20 \%$ dropout rate during the sample size calculation is much higher compared to previous studies, such as $10 \%$ for 10 weeks following handwashing intervention programmes among schoolchildren (Bowen et al. 2007).

\section{CONCLUSION}

The trained food handlers had significantly improved their handwashing frequency in Post 1 compared to the baseline ( $21.8 \%$ increment), although this improvement was not sustained up to the twelfth week post intervention. The positive impact of this intervention was also documented by the increment in the proportion of the correct handwashing technique in all the observed conditions in the intervention group compared to the control, even though it was statistically insignificant. Thus, indicating that the TPB-based FSEP offered a framework to improve handwashing practices in food handlers, and will ultimately reduce the risk of foodborne diseases in the school institution. Therefore, the content and strategies adopted in the education programme, based on the TPB framework, are ready to be used in similar or other relevant target populations.

\section{ACKNOWLEDGEMENTS}

The authors would like to acknowledge Universiti Sains Malaysia, Ministry of Education and Ministry of Health Malaysia for approving this research. A special dedication also goes to all the headmasters and teachers of schools involved in this research. The Universiti Sains Malaysia funded this study through the Short Term Grant (304/ PPSP/61313071).

\section{REFERENCES}

Abdullah Sani, N. \& Siow, O.N. 2014. Knowledge, attitudes and practices of food handlers on food safety in food service operations at the Universiti Kebangsaan Malaysia. Food Control 37: 210-217.

Ajzen, I. 1991. The theory of planned behavior. Organizational Behavior and Human Decision Processes 50(2): 179-211. 
Anderson, M.E., Sargeant, J.M. \& Weese, J.S. 2014. Video observation of hand hygiene practices during routine companion animal appointments and the effect of a poster intervention on hand hygiene compliance. BMC Veterinary Research 10(1): 106.

Bas, M., Safak, Ersun, A. \& Kivanc, K. 2006. The evaluation of food hygiene knowledge, attitudes, and practices of food handlers' in food businesses in Turkey. Food Control 17(4): 317-322.

Bowen, A., Ma, H., Ou, J., Billhimer, W., Long, T., Mintz, E., Hoekstra, R.M. \& Luby, S. 2007. A cluster-randomized controlled trial evaluating the effect of a handwashingpromotion program in Chinese primary schools. The American Journal of Tropical Medicine and Hygiene 76(6): 1166-1173.

Boyce, J.M. \& Pittet, D. 2002. Guideline for hand hygiene in health-care settings: Recommendations of the Healthcare Infection Control Practices Advisory Committee and the HICPAC/SHEA/APIC/IDSA Hand Hygiene Task Force. American Journal of Infection Control 30(8): S1-S46.

Brannon, L.A., York, V.K., Roberts, K.R., Shanklin, C.W. \& Howells, A.D. 2009. Appreciation of food safety practices based on level of experience. Journal of Foodservice Business Research 12(2): 134-154.

Chapman, B., Eversley, T., Fillion, K., MacLaurin, T. \& Powell, D. 2010. Assessment of food safety practices of food service food handlers (risk assessment data): Testing a communication intervention (evaluation of tools). Journal of Food Protection 73(6): 1101-1107.

Chapman, B., MacLaurin, T. \& Powell, D. 2011. Food safety infosheets: Design and refinement of a narrative-based training intervention. British Food Journal 113(2): 160-186.

European Food Safety Authority (EFSA). 2010. The community summary report on trends and sources of zoonoses, zoonotic agents, and food borne outbreaks in the European Union in 2008. The European Food Safety Authority Journal 8: 1-313.

Food and Drug Administration (FDA). 2003. Food and Drug Administration Fact Sheet on Hand Hygiene in Retail \& Food Service Establishments. http://www.fda.gov/Food/ GuidanceRegulation/RetailFoodProtection/schools: Effective infection control interventions. Journal of School Health 80(12): 588-598.

Lillquist, D.R., McCabe, M.L. \& Church, K.H. 2005. A comparison of traditional handwashing training with active handwashing training in the food handler industry. Journal of Environmental Health 67(6): 13-16.

Lues, J.F., Rasephei, M.R., Venter, P. \& Theron, M.M. 2006. Assessing food safety and associated food handling practices in street food vending. International Journal of Environmental Health Research 16(5): 319-328.

Meftahuddin, T. 2002. Review of the trends and causes of food borne outbreaks in Malaysia from 1988 to 1997. The Medical Journal of Malaysia 57(1): 70-79.

O’Boyle, C.A., Henly, S.J. \& Larson, E. 2001. Understanding adherence to hand hygiene recommendations: The theory of planned behavior. American Journal of Infection Control 29(6): 352-360.

Park, S.H., Kwak, T.K. \& Chang, H.J. 2010. Evaluation of the food safety training for food handlers in restaurant operations. Nutrition Research and Practice 4(1): 58-68.

Pascual, P.A.L. \& Abenis, N.F.L.D. 2016. Assessment of the sanitary conditions and food handlers' practices of public and private high school canteens in Eastern Visayas, Philippines. Countryside Development Research Journal 4(1): 1-9.

Pragle, A.S., Harding, A.K. \& Mack, J.C. 2007. Food workers' perspectives on handwashing behaviors and barriers in the restaurant environment. Journal of Environmental Health 69(10): 27-31.

Rennie, D.M. 1995. Health education models and food hygiene education. The Journal of the Royal Society for the Promotion of Health 115(2): 75-79.

Ryu, J.H., Ko, J., Park, H., Yang, S. \& Kim, H. 2011. Microbial examination of nonheated foods served in feeding programs of elementary schools, Iksan City, Jeonbuk Province, Korea. Journal of Food Protection 74(9): 1564-1568.

Sani, N.A. \& Siow, O.N. 2014. Knowledge, attitudes and practices of food handlers on food safety in food service operations at the Universiti Kebangsaan Malaysia. Food Control 37: 210-217.

Seaman, P. \& Eves, A. 2006. The management of food safety the role of food hygiene training in the UK service sector. International Journal of Hospitality Management 25(2): 278-296.

Sharif, L., Obaidat, M.M. \& Al-Dalalah, M.R. 2013. Food hygiene knowledge, attitudes and practices of the food handlers in the military hospitals. Food and Nutrition Sciences 4(3): 245-251.

Sharma, A.K., Saxena, S. \& Sharma, S. 2016. Hand washing knowledge, attitude and practices among medical students. Indian Journal of Scientific Research 7(1): 159-164.

Simonne, A., Brecht, J., Sargent, S., Ritenour, M. \& Schneider, K.R. 2010. Good worker health and hygiene practices: Training manual for produce handlers. Food and Agricultural Sciences' General Collection, University of Florida IFAS Extension. 1-11. http://edis.ifas.ufl.edu/fy743. Accessed on April 2015.

Somura, Y., Kimoto, K., Oda, M., Okutsu, Y., Kato, R., Suzuki, Y. \& Sadamasu, K. 2017. Serial food poisoning outbreaks caused by norovirus-contaminated shredded dried laver seaweed provided at school lunch, Tokyo, 2017. Shokuhin eiseigaku zasshi. Journal of the Food Hygienic Society of Japan 58(6): 260-267.

Soon, J.M., Singh, H. \& Baines, R. 2011. Foodborne diseases in Malaysia: A review. Food Control 22(6): 823-830.

Tan, S.L., Bakar, F.A., Abdul Karim, M.S., Lee, H.Y. \& Mahyudin, N.A. 2013. Hand hygiene knowledge, attitudes and practices among food handlers at primary schools in Hulu Langat district, Selangor (Malaysia). Food Control 34(2): 428-435.

Webb, M. \& Morancie, A. 2015. Food safety knowledge of foodservice workers at a university campus by education level, experience, and food safety training. Food Control 50: 259-264.

York, V.K., Brannon, L., Shanklin, C.W., Roberts, K.R., Barrett, B.B. \& Howells, A.D. 2009. Intervention improves restaurant employees' food safety compliance rates. International Journal of Contemporary Hospitality Management 21(4): 459-478.

Zain, M.M. 2001. A study on effectiveness of health education program on knowledge, attitude and practice of food handlers towards foodborne diseases and food safety. (Dissertation). Master Thesis. Community Medicine, USM, Kota Bharu, Malaysia (Unpublished). 
Nik Rosmawati NH*

Department of Community Medicine

School of Medical Sciences, Health Campus

Universiti Sains Malaysia

Kubang Kerian, Kelantan Darul Naim

Malaysia

Wan Manan WM

Khazanah Research Institute

Level 25, Mercu UEM

Jalan Stesen Sentral 5

Kuala Lumpur Sentral

50470 Kuala Lumpur, Federal Territory

Malaysia

Noor Izani NJ

School of Health Sciences, Health Campus

Universiti Sains Malaysia

16150 Kubang Kerian, Kelantan Darul Naim

Malaysia
Nik Nurain NH

Food Safety and Quality Division

Kelantan State Health Department

16100 Kota Bharu, Kelantan Darul Naim

Malaysia

\section{Razlina AR}

Department of Family Medicine

School of Medical Sciences, Health Campus

Universiti Sains Malaysia

16150 Kubang Kerian, Kelantan Darul Naim

Malaysia

*Corresponding author; email: rosmawati@usm.my

Received: 4 December 2017

Accepted: 14 May 2018 